\title{
プロダラムフリーザーによる培银細胞の梠結保存に閉する研究
}

\author{
吉屋 誠・木村䓯孝・角田左武郎 \\ 南雲正男・梗本昭二
}

\section{Studies on cryoconservation of cultured cells by programmed freezer}

\author{
Makoto YoshiYa - Yoshitaka KImURA - Saburo Kakuta \\ Masao Nagumo - Shoji Enomoto
}

粕

近年，培㩐技術の向上に伴い数多くの細胞株が樹立さ れ，それらは免疫学的1 な゙ならびに癌の細胞レベルの解 析1,5)等において，われわれに幾多の情報をむたらして きた。しかし培着細胞は実殹室内で常にカビあるいは雜 菌による contamination の危険にさらされており，細 胸株相互の contamination の 可能性すあるといわれて いる．また培養細胞は継代中に性質が少しずつ変化し， origin となった細胞の本来の特性が失われると考えられ ている ${ }^{6,7)}$.

一般に培養細胞を用いて再現性のある実験を行らため には，細胞の持っている種々の性状を変化させることな く保存する必要がある。このような目的から，培養細胞 の長期保存に凍結保存法が一般に用いられている8 10). 倲結による細胞の保存はすでに血球 ${ }^{11,12)}$ ，精子 ${ }^{13)}$ 等に応 用されているか， 口腔領域でも将来歯肧の長期保存など に利用しらる可能性も考えられる。

今回われわれは凍結, 解凍を自由に制御できるブロク ラムフリーザーを用い，Ca 9-22 細胞，HeLa S-3 細胞 および RTG 細胞の凍結保存ならびに解倲後の生存性, 增殖性に関して検討し若干の知見を得たので報告する。

\section{実験材料および方法}

\section{1. 使用細胞株}

使用した細胞は1972年歯肉扁平上皮癌より樹立された

昭和大学䅈学部第 2 口腔外科学教室（主任：榎本昭 二教授)

The second Department of Oral Surgery, School of Dentistry, Showa University (Chief: Prof. Shoji Enomoto)

受付日：昭和56年 1 月 25 日
Ca 9-22 細胞 ${ }^{14)}$ ，黑人子宮项瘦に由来する HeLa S-3 細

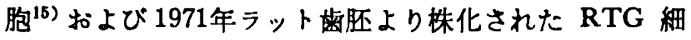
胞 ${ }^{16)} 3$ 種の細胞株を用いた。

\section{2. 培䇾液および保存波}

培養液は $20 \%$ 仔牛血清添加 Eagle's minimum essential medium (ニッスイ,以下 MEMと略す) を用い, $5 \% \mathrm{CO}_{2}$ s卯器で静盾培養した。凍結保存液には，こ の培着液に倲結防止剤として di-methyl sulfoxide (Sigma, DMSO と略す) を所定濃度加えて用いた。

\section{3. 細胞浮遊液の調整}

凍結を行う前日に培善液を交換した細胞株を凍結直前 に $0.05 \%$ trypsin-PBS で細胞浮遊液とし, MEMで 2 回 洗浄した後再浮遊した。 あらかじめ DMSO は MEM との等量溶液を水水中で作成し，この細胞浮遊液にこれ の水水中で所定灌度加えて, 最終的に $1 \times 10^{6} / \mathrm{ml}$ の細 胞浮遊液になるよらに調整した。これを $2 \mathrm{ml}$ の注射用 アンプルに $1 \mathrm{ml}$ ずつ分注溶封して凍結実験に用いた。

\section{4. 使用器機}

プクラムフリーザーは Planner 社製の R201/200R を用いた，これは $-180^{\circ} \mathrm{C}$ から $+25^{\circ} \mathrm{C}$ の簀囲で倲結 および解凍を制御できるように設計されている，凍結の 一部および凍結後の保存は, $-80^{\circ} \mathrm{C}$ に調整したディー ブフリーザー（エパラ, ESL 100）を用いた.

\section{5. 凍結および解凍方法}

凍結はブログラムフリーザーでー $2^{\circ} \mathrm{C} /$ 分およびー $10^{\circ}$ $\mathrm{C} /$ 分の条件, ドライフイス・アセトン溶液およびディー ブフリーザーに直接投入して倲結する 4 種の方法で行っ た.

解凍はブログラムフリーザーで+2 ${ }^{\circ} \mathrm{C} /$ 分および+10。 $\mathrm{C} /$ 分の条件と $37^{\circ} \mathrm{C}$ 恒温水槽で急速解倲する方法で行っ た．したがってこれらの涷結および解倲の条件を組み合 わせ, 表 1 のうに 5 種類の方法でそれぞれの細胞株に つき検討した，以後それぞれの方法をこの表に記載した 記号で表わす。 


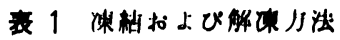

\begin{tabular}{|c|c|c|}
\hline 菋 絬 j 法 & 解 谋 j 法 & 䟕 早 \\
\hline ト゚ライフイス・フセトン海液 & $37^{\circ} \mathrm{C}$ 恒淈水栦 & $\mathbf{D}-\mathbf{R}$ \\
\hline ディーフフリーザー & $37^{\circ} \mathrm{C}$ 㠶温水情 & $d-R$ \\
\hline$-2^{\circ} \mathrm{C} /$ 分 プログラムフリーザー & $37^{\circ} \mathrm{C}$ 愐温水槽 & 2-R \\
\hline $\begin{array}{l}-2^{\circ} \mathrm{C} / \text { 分 プログラムフリーザー } \\
-10^{\circ} \mathrm{C} / \text { 分 プロクラムフリーザー }\end{array}$ & 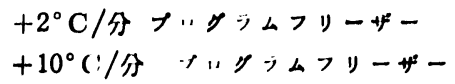 & $\begin{array}{r}2 P \\
10 P\end{array}$ \\
\hline
\end{tabular}

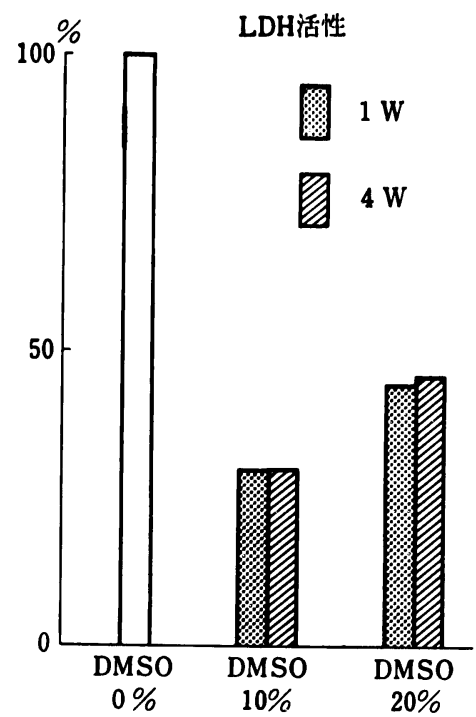

図 1 プログラムフリーザーによる DMSO 算度の検討（HeLa S-3 細胞）

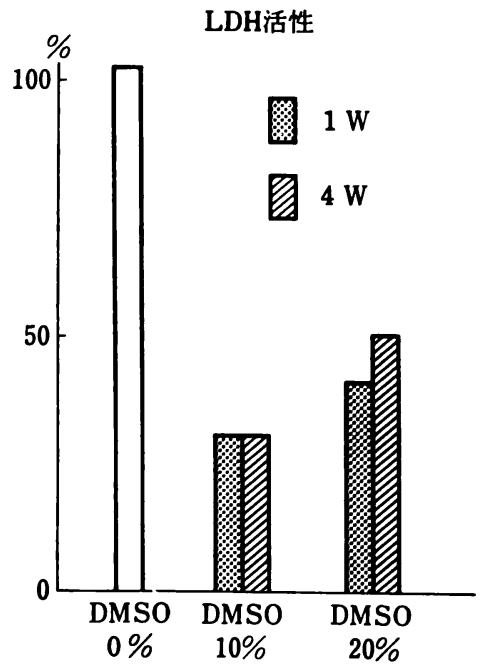

図 2 ディープフリーザーによる DMSO 瀵度の検討 (HeLa S-3 細胞)

\section{6. 呯価の方法}

それぞれの方法で解饥したンフルを碚ちに閏封して

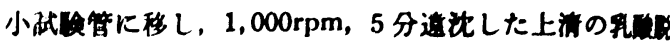

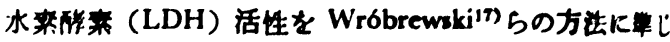

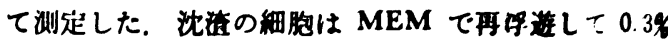
trypan blue dye exclusion で viability を蜼した。 さ らにこの細胞浮遊湤を们往 $17 \mathrm{~mm}$ のブラスチックシャ ーレ（マルチウェルブレート Falcon 社）で secondary culture を行った. すなわち1ウっルあたり $1 \times 100$ 田

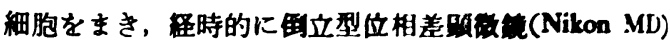
で覞察した。

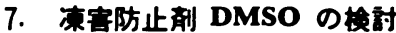

保存洨に添加する DMSO 漫度を决定するために HeLa S-3 細胞を使って予侕实除を行った。 すなわち DMSO を加えずに培费花のみ，で保存した场合（0\% DMSO と表わす）と，DMSO を10\%および20\%元え た保存液について， $-2^{\circ} \mathrm{C} /$ 分ブロクラムフリーサーあ るいは $-80^{\circ} \mathrm{C}$ ディーブフリーザーに直接いれて踏し

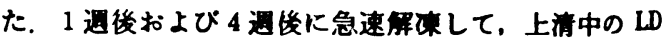
H 活性および secondary cultureを行い娭討した。 国1 および因 2 は DMSO を活加しない㧹合の上清の LDH 活性を $100 \%$ として表わした結果である．いずれの方法 においてる，10\% DMSO を加えた保有砤が最るLDH 活性が低く 1 週後および 4 㯰後とるに $30 \%$ 前後です。

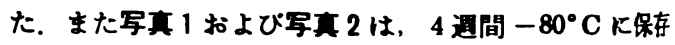
した HeLa S-3 細胞を48時間 secondary culture した位 相差暊徽鏡写真である. いずれの方法でも DMSOを 加しない場合は紐胞破埢が著しく一部ウェル底面に付着 しているがほとんど增殖していない. 10\% DMSOては ウェル全面に数石状に增直し，分裂像む数多くみられ た. また $20 \%$ DMSO を加えてブロクラムフリーサー で倲結した坸合は，ウェル底面の半分程度に增直してお り，20\% DMSOを加えてディーフフフリーザーに直接入 れて凍結した场合には，ウェルの約 $1 / 3$ に付着增殖して いる細胞が琹められた。

以上の結果から，ブロクラムフリーザーによる軥合て あ，ディープフリーザーによる場合でも倲害防止削とし て DMSO を $10 \%$ 加えた保存液が，上清中の LDH活 性が最す少なく解倲後の secondary culture の位相差盾 


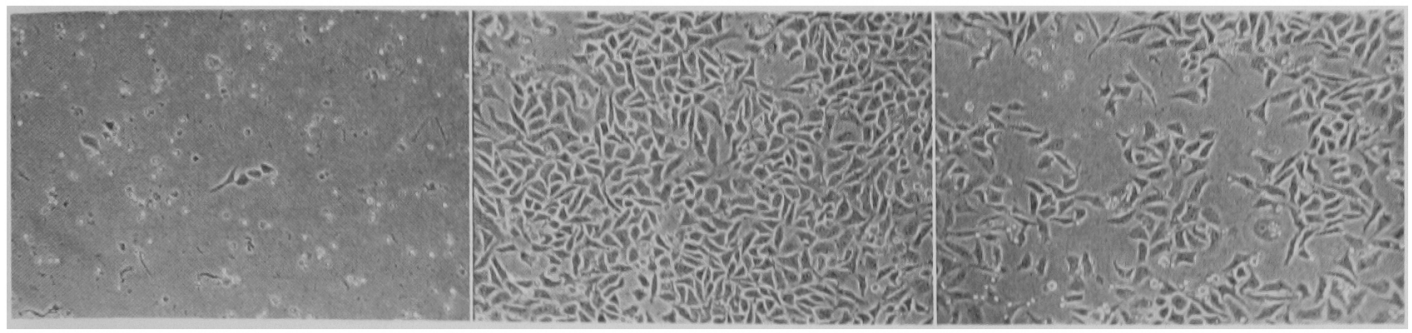

$0 \%$

$10^{\circ}$

$20 \%$

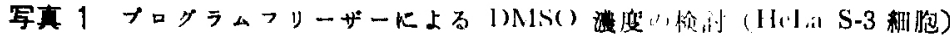

4 週間濑枯作後 secondary culture 2 日目 $(\times 100)$

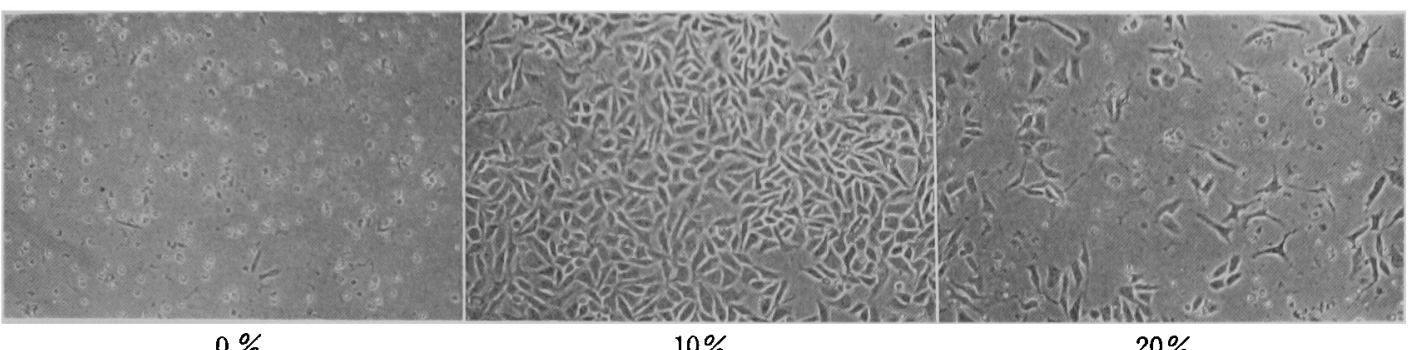

$0 \%$

$10 \%$

$20 \%$

写直 2 ディーフフフリーザーによる DMSO 澄度の検討（HeLa S-3 紐胞）

4 週間涷結保存後 secondary culture 2 日目 $(\times 100)$

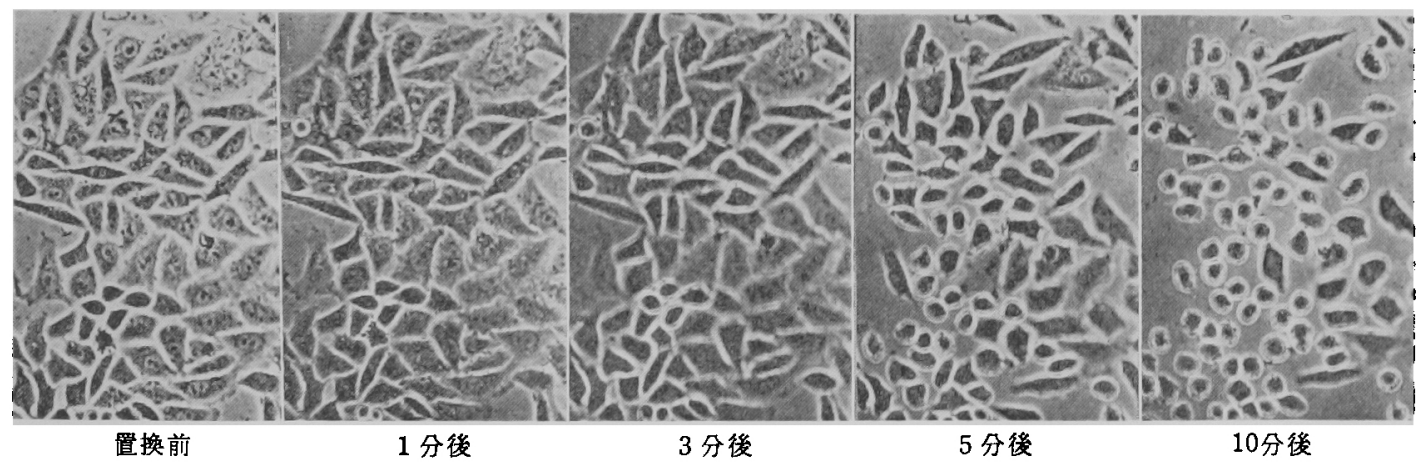

写真 $310 \%$ DMSO の影整，位相差蝢微鏡映画加 5の写真 (HeLa S-3 細胞, $\times 200)$

微鏡による観察の結果す良好であった。したがって本実 験に拁いては $10 \%$ DMSO を用いて行った。

さらに凍害防止剂 DMSO の細胞付対する直接的影 響を HeLa S-3 細胞を用いて位相差顕微鏡映画 (Nikon MD, Bolex H-16) で観察した．細胞をTD-15型培養ビ ンで培着し培養液と $10 \%$ DMSO を含んだ保存夜を゙還 流置換したところ，写真了でみられるように置換して3 分後には形態的な変化が現われ，10分後には細胞相互の 接触が完全に消失し球形を呈した。
実 験 結 果

\section{Ca 9-22 細胞}

保存液上清中の LDH 活性は 1 週後で D-R が 162, $\mathrm{d}-\mathrm{R}$ かं $140,2-\mathrm{R}$ かं $144,2 \mathrm{P}$ かi $146,10 \mathrm{P}$ かं 164 と なり，4 週後では D-R が 186， d-R が 150，2-R が 150，2P が 165，10 P が 165 であった（図 3）。また trypan blue dye exclusion では体結前は $92 \%$ たった が, 4 週後で D-R が $50 \%$, d-R か 50\%，2-R が 64.9 


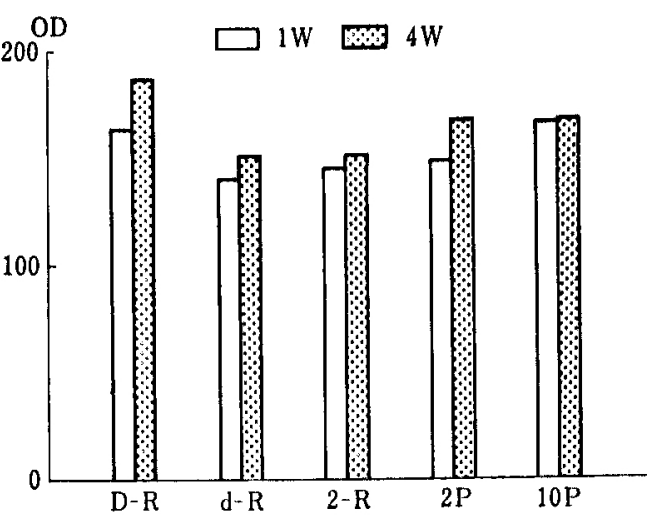

图 3Ca 9-22 科胞に括ける保作液上消中の $\mathrm{LDH}$ 活性

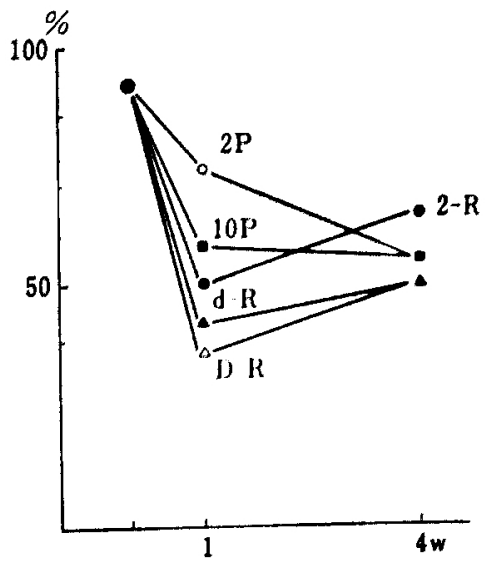

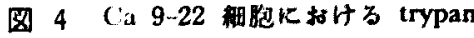
blue dye exclusion

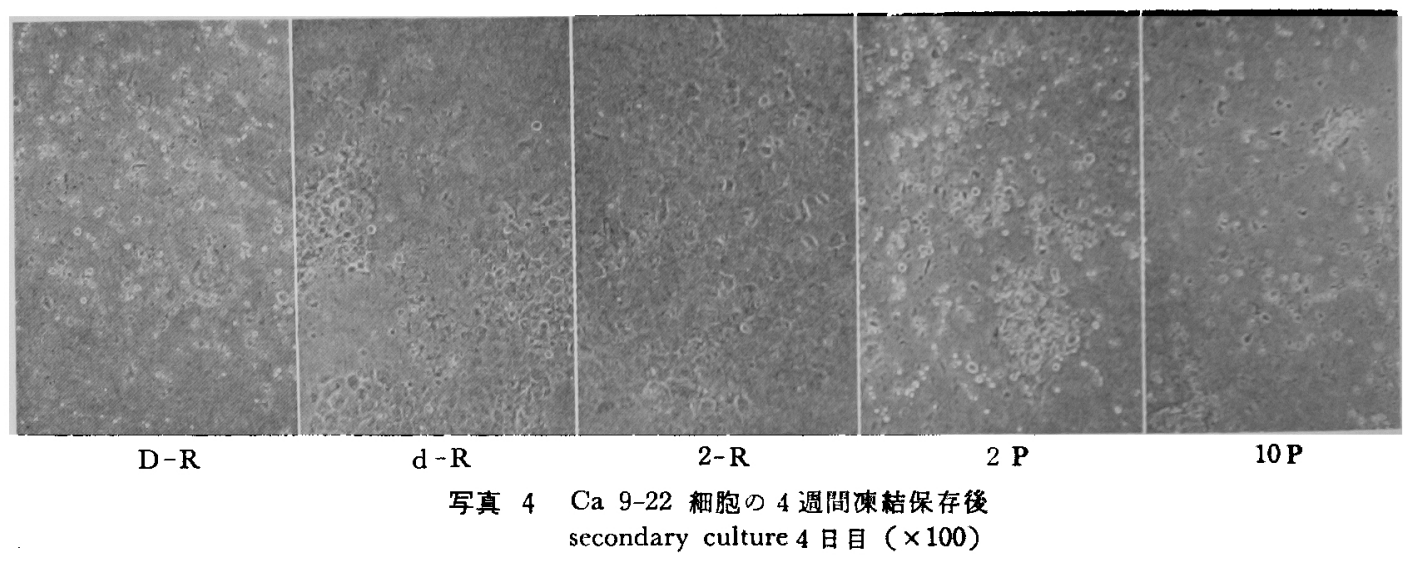

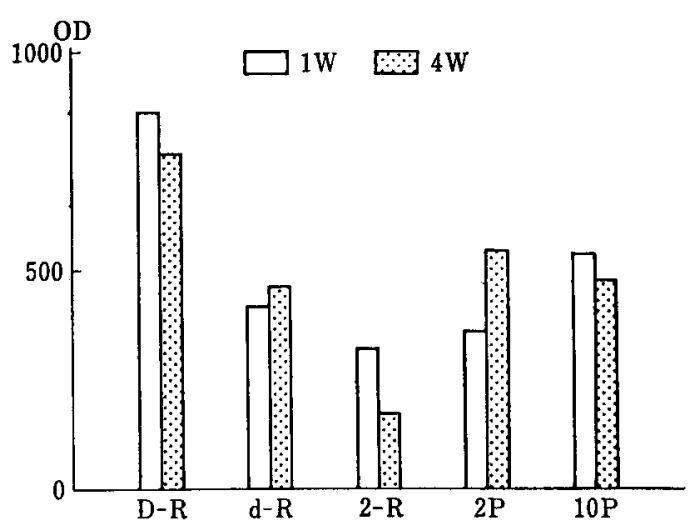

图 5 HeLa S-3 細胞に的ける保存液上清中 の $\mathrm{LDH}$ 活性

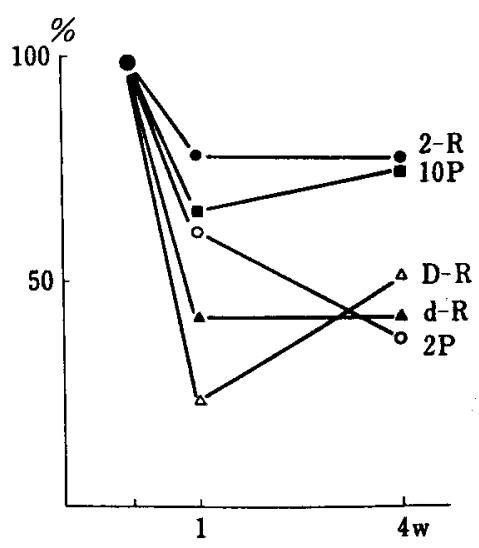

图 6 HeLa S-3 和胞に括忛万 trypan blue dye exclusion 


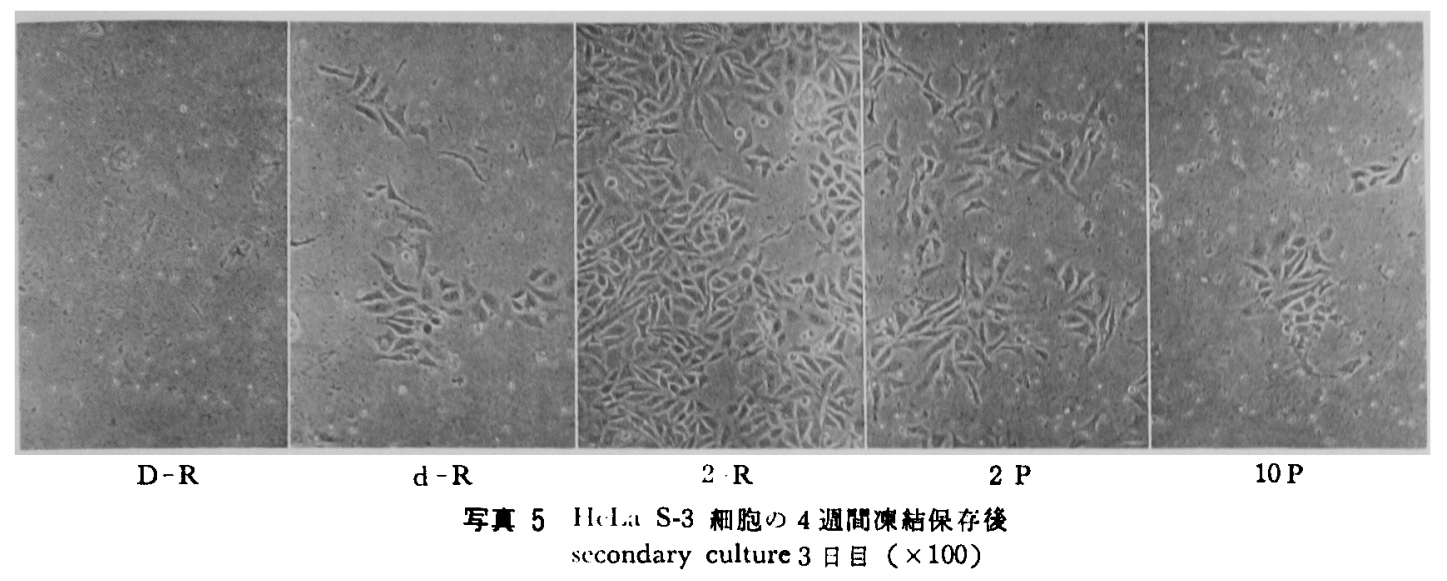

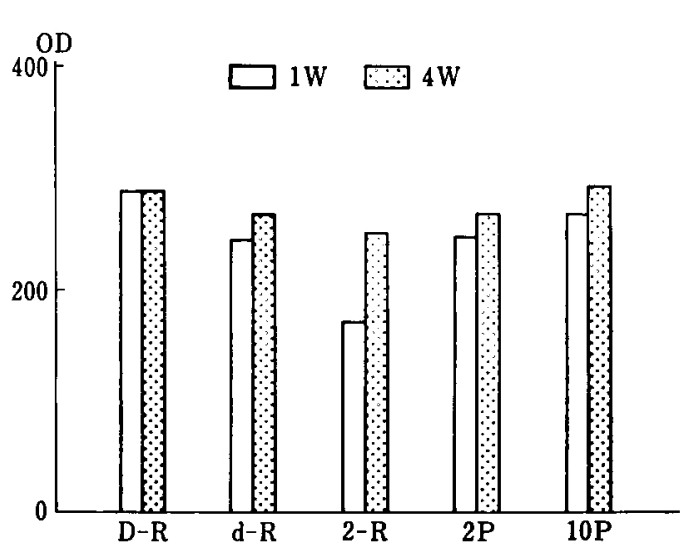

図 7 RTG 級胞における保存液上清中の $\mathrm{LDH}$ 活性

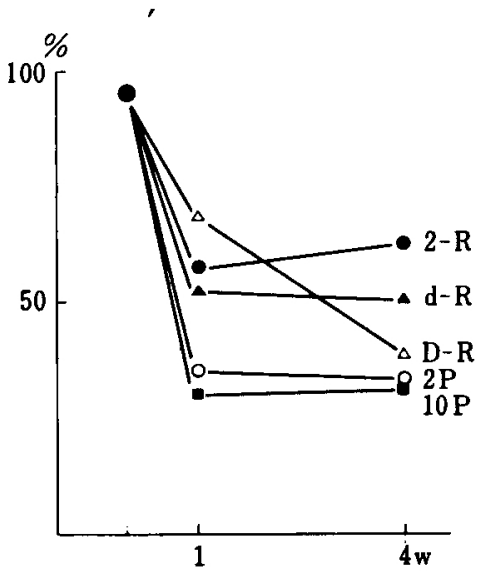

图 8 RTG 湅胞における trypan blue dye exclusion

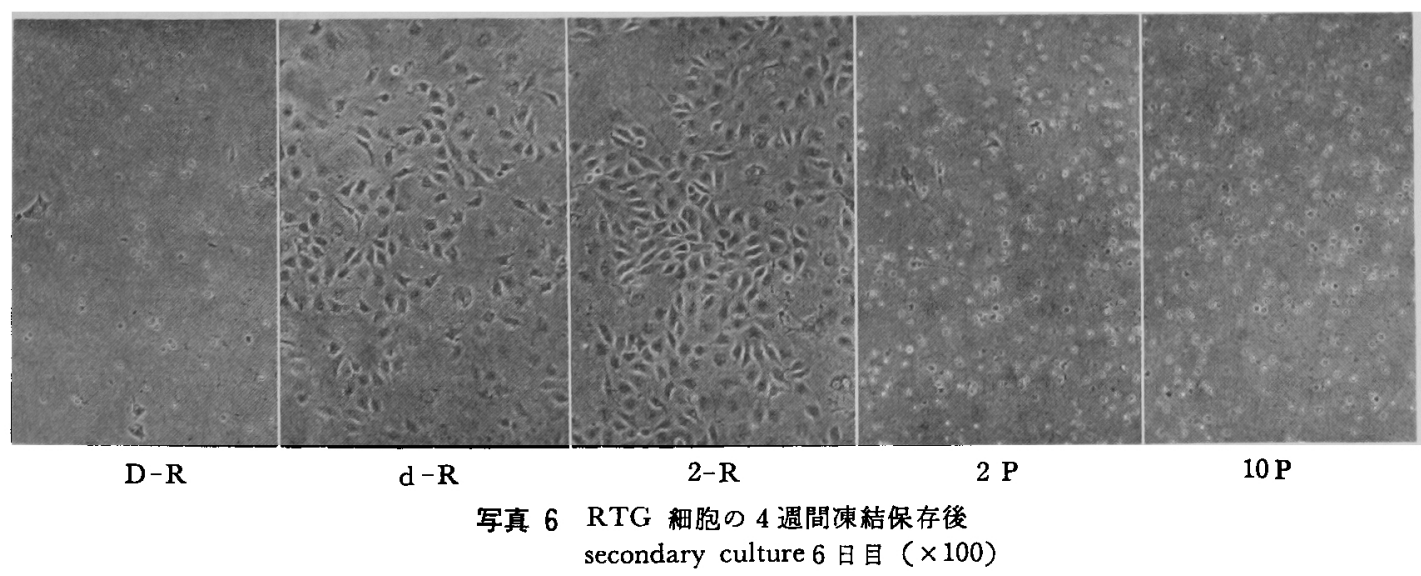


$\%, 2 \mathrm{P}$ か $53.9 \%, 10 \mathrm{P}$ が $53.8 \%$ を小した（图 4).

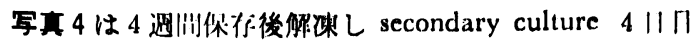
の位相差湿微鏡写真であるが，2-R の方法が聚もよくウ ェルのほぽ全面に增殖していた。

\section{HeLa S-3 細胞}

LDH 活性は， 1 週後 D-R かi 864， d-R が 412, 2-R が 320，2P が 352，10P が534で速後では D-R かi 762, d-R かi 468, 2-R かi 171, $2 \mathrm{P}$ かi 543, $10 \mathrm{P}$ が 474 となっており 2-R が藉明に低い做を示した (图 5). trypan bluc dye exclusion では洙結削が $98 \%$ に対して 4 用後で D-R かi $50 \%$ ，d-R が $41.2 \% ， 2-R$ か $76.2 \% 、 2 \mathrm{P}$ か $37.1 \% 、 10 \mathrm{P}$ が $77.2 \%$ であった

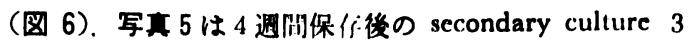
日目の位相差顕微鏡所見である. 2-Rの方法の们はす

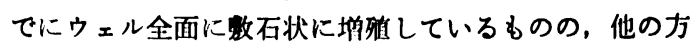
法の場合にも 2-R ほどではないが多数のコロニーを形 成して增殖していた。

\section{RTG 細胞}

LDH 活性は 1 週後で D-R かi $286, d-R$ か 244 , 2-R か 170，2P が 248, $10 \mathrm{P}$ か 266 となっており, 4 週後では D-R が 282, d-R が267, 2-R が 249, 2 P が 267, $10 \mathrm{P}$ が 291 で4週後では 1 週後のデータより 差が小さかったが 2-R の値が低い値を示した（図 7). trypan blue dye exclusion では凍結前が95\%に対して, 4 週後で D-R かi $37.7 \%$, d-R かi 50\%，2-R か 62.1 $\%, 2 \mathrm{P}$ か3 $33.3 \%, 10 \mathrm{P}$ か $31.3 \%$ となっており（因 8), Ca 9-22 細胞および HeLa S-3 細胞と同し佰向を 示した． 4 週間凍結保存後の secondary culture の所見 では培養後 2〜3日ではほとんど差が認められず，すぺ て球形を呈してウェル底面に付着していた。培算 5 日目 ぐらいから徐々に細胞が抝かりりじめ增殖を示した，写 真 6 は secondary culture 6 日目の所見であるが 2-R の 方法はウェルの約 $80 \%$ を占めており，他の細胞の場合と 同様に最も良く増殖している状態が観察された。 $10 \mathrm{P}$ は Ca 9-22 細胞の 4 日目の状態よりさらに悪く、息 んどの細胞が球形でウェルに付着したままであった。

\section{考察}

細胞培堆の技術は，近年免疫学( ${ }^{(2)}$ をはじめ㴼の研究 等のいろいろな分野で不可欠なものとなっている，培養 紐胞を用いて再現性のある実験系を組むためには，その 細胞の保持している性状を变化させることなく保存維持 する必要がある。しかし培着細胞は継代中に徐々に性状 の変化が生ずると考えられており ${ }^{6,7}$ ，継代培養のわず らわしさと継代に伴ら種々の性状の変化を避けるため に, 凍結による保存が一般に利用されている8

細胞の凍結保存は1900年代に入ってそのメカニズム， 凍害および解凍後の変化等が盛んに研究され, さらに凍

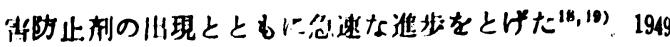

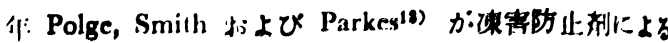

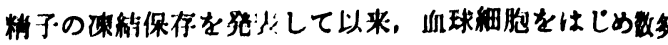

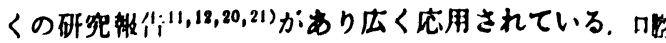

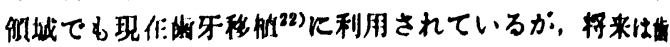

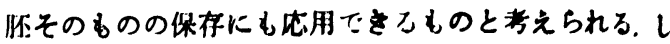

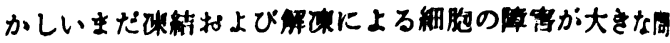
咀とされている。

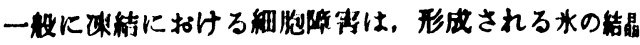

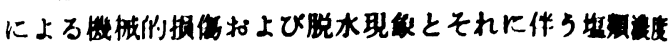

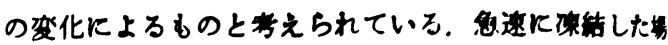

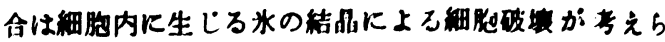

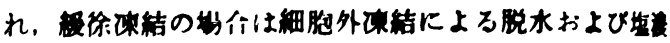

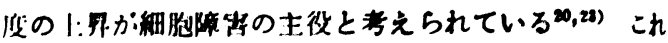

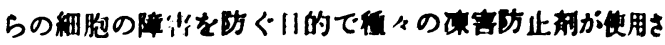

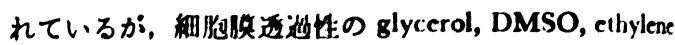
glycol 等と非逐遇性の dextran, PVP, lactose, glucour,

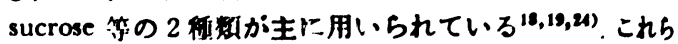
のらちであ glycerol と DMSO が多く用いられて おり, Niwayama ${ }^{23)} ら は$ DMSO の方が glycerol と比

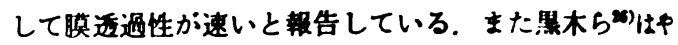
はり glycerol と比べて L-1210 細胞の解柘後の生存革占 よび移植率とすに DMSO の方が磼实な保言作用を有す ると述へてている，他方骨链細胞を用いての実(

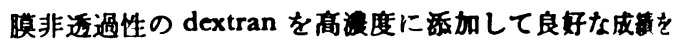

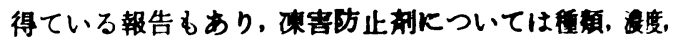
使用法ならびに洁結一保存一解湅方法についてさらに今 後の研究が必要なるのと思われる。

今回われわれは农害助止雵として DMSOを用いた

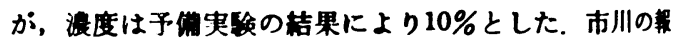

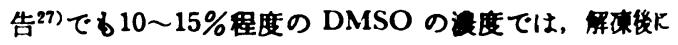
培蒦した細胞内の LDH 活性が低くなるが攻死的影田 ないと報告している。しかし写草了のよらに 10\% DM SO を含む保存液を添加すると，数分で形態的な变化が 現われ10分後には細胞相互の接䖵か完全に消失し增策の

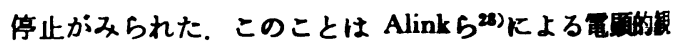
察で 2.5\% DMSO では形龍的变化は証められないか,

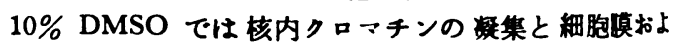
びミトコンドリフの破垻が起こるとの報告と一致してお ク，DMSO は細胞に対して短時間でなんらかの直接的 影整を及注するのと考えられる。ささらに DMSO は発整 性であることから、一般に行われているよ5に29,0) DMSO の操作は氷水中で施行する必要があり，凍赫 は可及的に短時間の操作で行ら必要があると思われる. また市川は細胞膜透過性の DMSO が解涷後に培養した

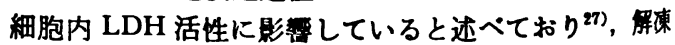
後の細胞は直ちに培養液で先浄し，DMSO を可及的に 早く除去することが望ましいと思われる.今回 DMSO の涱度については HeLa S-3 細胞で俟討し，10\%前牧 


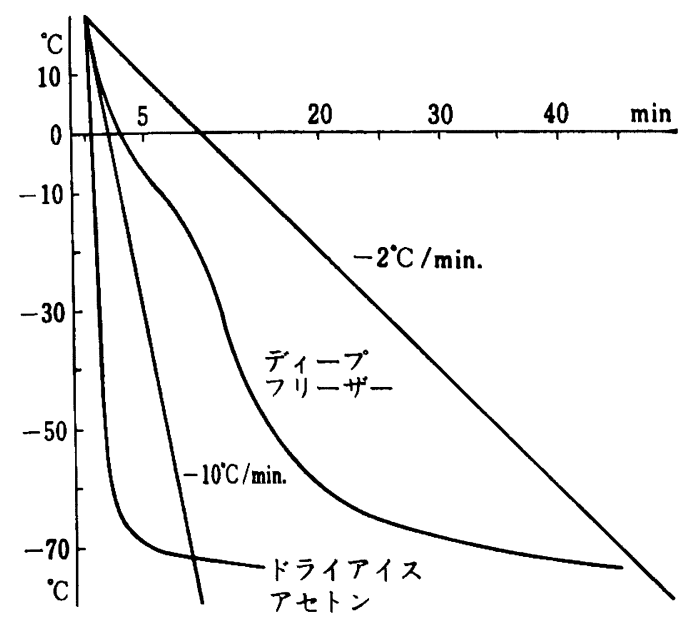

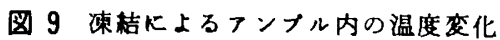

が良い結果を得たが，DMSO が細胞膜透過性で解倲後 も細胞内に残留することから考えると，細胞の種類によ って DMSO に対する感受性および浱度の影繁に差が ることも十分に推测される.

倲結時の椧却速度に関しては種々の報告がある. Rowe ${ }^{31)}$ は $0.1^{\circ} \mathrm{C} /$ 分 で非常にゆっくり凍結すると大き な氷晶が細胞外に生し，胸胞の脱水と塩類濃度の上昇の ため細胞は死に至り, $1 \sim 10^{\circ} \mathrm{C} /$ 分で涷結した時は氷晶の 成長は遅く，脱水も起こりにくいため高い生存率を得る と報告している。 また 1 分間に $10^{\circ} \mathrm{C}$ 以上の急速凍結で は細胞内に氷の結晶が生成され，細胞は著しく致死的障 害を受け，さらに速い瞬間倲結の時は細胞内に氷晶を作 らず無定状態 (vitreous ice) となるため細胞障害は少な いと述べている，一般に容液を楥徐凍結すると液相から 固相になる時に過冾却となり，潜熱の放出によって倲結 プラトーを生じ移行相 (aqueous-ice transformation) の 状態を释過する。 この移行相を $1 \sim 2^{\circ} \mathrm{C} /$ 分の一定速度 で短時間に通過した時に, 最も高い細胞の生存率を得る といわれている. しかし従来の凍結方法ではフンプル内 の冷却速度を一定に制御することは非常に困難である. Pawtel ら22)の報告にもあるようにチ+ンパーとフンブル との温度差は, 移行相で非常に大きく現われるが，今回 われわれが用いたプログラムフリーザーではセンサーを 保存アンプルと同じ条件のアンプルに入れ，電磁弁を一 $2^{\circ} \mathrm{C} /$ 分の時は 1 分間に 150 回, $-10^{\circ} \mathrm{C} /$ 分の時は 200 回 開閉させることにより，図9のように $-5^{\circ} \mathrm{C}$ から -15 ○Cの間をほとんど直線的にすることができた。

解凍に関しては急速に暖めた場合には，氷晶の成長速 度の大きい範囲を急速に通過するため, 水の結晶は細胞 に害を与える程大きくならず細胞は生存するが, 緩徐解 倲の場合には办晶が細胞に有害となる大きさに成長する

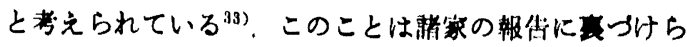
れて拈り，われわれの絬果と一政している.

胫結保存による培細胞への影瞥は viability の面か らは dye exclusion, lysosomal enzyme および cytoplasmic enzyme, 生物学的怡:状をみるためには secondary

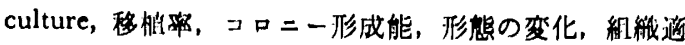

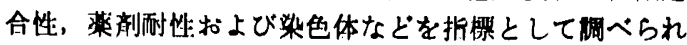
ているが，これらのらちいくつかを使って総合的に判起 しなければならない

今回の夷䂆においては細胞の生死の判定に trypan blue dye exclusion を用いたが，本法は操作が非㦂に偭 単で短時間にできることから広く利用されている。しか し細胞障害が著しく，破液され麾と化した細胞は除外さ れる点が trypan blue dye exclusion の不利な点と思わ れる.この点から細胞の viability を知るには, cytoplasmic enzyme の活性を測定するのが最も合理的と考え られる. しかも保存液中の LDH 活性を測定する方法は 比較的容易で, trypan blue dye exclusion との併用は非 常に有用之思われる。因 4 の Ca 9-22 細胞, 图6の HeLa S-3 細胞にみられるように D-R または 2-R が 1 週後に比べて 1 週後の生存率か上昇しているのは, 倲 結保存中に破壤されてしまら細胞の多いことが推測され る.しかし図8の RTG 細胞における D-R のよ5に, 1 週後の方が 4 週後よりも生存率が高くなっており，細 胞によって耐谏性に明らかな差があるものと考えられ る.

また保存液中の LDH 活性値の面からみると図3のよ らに Ca 9-22 細胞においては涷結, 解倲の方法による 差はわずかに認められ， 1 週から 4 週の間にいずれの方 法でも軽度に上昇している。つまり凍結時の細胞破壊の 方が保存中に破堎される量に比べて非常に大きいるのと 考えられる。

secondary culture による判定は定量性に乏しいが写 卉 4 〜 6 にみられるように単位面積あたりの細胞数を適 当に選ぷことにより，効果判定に十分に利用できるるの と考えられる，すなわち，植え込み細胞数と細胞の增殖 性の違いを考虑して培養時間を選択することにより, 倲 結保存方法による明らかな差違を認めた。 しかし DMSO は細胞膜透過性を持ち培兹後の細胞内 $\mathrm{LDH}$ 活性に 影敕する点から考えると，さらに長時間の凍結保存と長 期培羡の結果を観察する必要があると思われる。

以上のように trypan blue dye exclusion, 上清中の LDH 活性および secondary culture により凍結保存方 法の検討を行ったが，総合的に判断していずれの細胞に おいても $-2^{\circ} \mathrm{C} /$ 分で東結させ, $37^{\circ} \mathrm{C}$ 恒温水慒で急速 に解凍する方法が最も良い結果を得た。しかしディープ フリーザーに直接入れて凍結する方法も, 単に細胞の長 期保存を目的とする場合には十分に利用できるるのと考 えられる。 
結

\section{铻}

われわれはブログラムフリーザーを用いて Ca 9-22 緗 胞, HeLa S-3 細胞およびRTG 細胞を攻結保存し，解 凍後の生存性を LDH 活性, trypan blue dye exclusion で, 增殖性を secondary culture て程時的に榆时し以下 のよらな結果を得な。

1. 㧲害防止削 DMSO の湴度は $10 \%$ が最む良い結果 を得た。

2. 培葬細胞に対する 10\% DMSO を含む保存液の

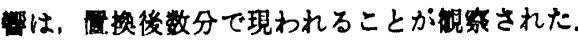

3. 谏結方法はー $2^{\circ} \mathrm{C} /$ 分ブログラムフリーザーによる 緅徐揀結が取も良い結果を得た。

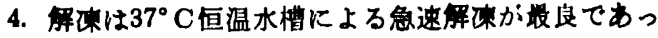
た.

5. ディーブフリーザーで湅結させ， $37^{\circ} \mathrm{C}$ 佰温水槽で 解凍する方法す細胞の長期保存といら面では有妙であっ た.

本論文の要旨は第34回日本口腔科学会總会（昭和55年 5 月16日 於岡山）において発表した。

\section{引用 文 献}

1）藤林孝司，佐藤 攸，藤村长久，他：口腔洎患

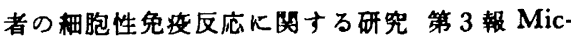
rocytotoxicity assay. 蹈床免 9: 1111 1977.

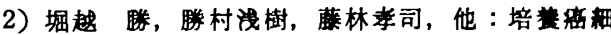
胞 (Ca 9-22) に対するリンパ球の栶胞障害作用 比関す万研究，日口外誌 23：619 1977.

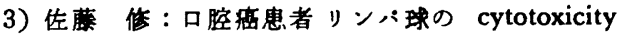
における effector cell の研究。 日外就 24: 10291978.

4）木村義孝：齿肉癌由来細胞株（Ca 9-22）の光 酸脱水素醉素関する研究。口病誌 45: 20 1977.

5）勝村浅樹：口腔癌患者のリンパ球に上る CellMediated Cytotoxicity に関す万研究。日口外 誌 26: 6431980 .

6) 中井進之助, 他：組機培善。第 1 版, 朝會書店, 1976, 168頁.

7) Torrey, J. G.: Morphogenesis in relation to chromosomal constitution in long-term plant tissue cultures. Physiol Plant 20: 2651967.

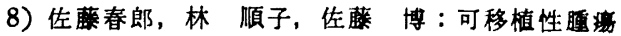
系の低温保存と䍃細胞の生物学的特性。低温医 学 1: 1951975.

9）佐藤春郎，鄉内俊克，佐藤博：細胞凍結と Cryoimmunology, 癌細胞の免疫学的ならびに 遗伝学的な変化。低温医学 3: 211977.

10）多和钽一, 涌本昇, 藤田 厚, 他：液体空素

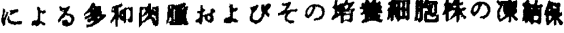

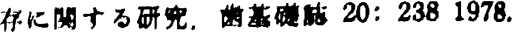

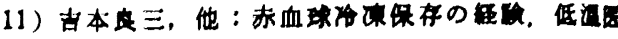
等 2: 131976 .

12) Spector, J. I., Yarmala, J.A., Marchionni, L.D., et al.: Viability and function of platel. ets frozen at 2 to $3^{\circ} \mathrm{C}$ per minute with 4 or 5 percent DMSO and stored at $-80^{\circ} \mathrm{C}$ for 8 month. Transfusion 17: 81977.

13) Polge, C., Smith, A.U., Parkes, A.S.: Revival of spermatoza after vitrification and dehydration at low temperatures. Nature 164: 666 1949.

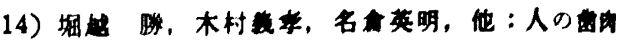

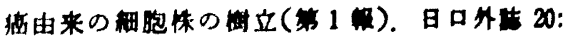
1001974.

15) Gey, G.O., Coffman, W.D., Kubicek, M.T.: Tissue culture studies of the proliferative capacity of cervical carcinoma and normal epithelium. Cancer Res 12: 2641952.

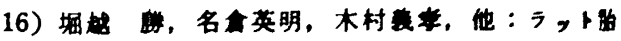

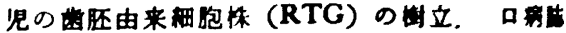
46: 2111979.

17) Wróblewski, F., La Due, J.S.: Lactic dehydrogenase activity in blood. Proc Soc Exp Biol Med 90: 2101955.

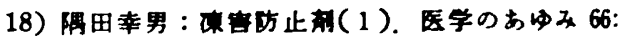
491968

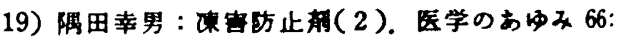
1031968.

20) Lovelock, J.E.: The haemolysis of human red blood-cells by freezing and thawing. Biochim Biophys Acta 10: 4141953.

21) Lovelock, J.E.: Het mechanism of the protective action of glycerol against haemolysis by freezing and thawing. Biochim Biophy Acta 11: 281953.

22）山根稳夫：齿の错行一低温保存齿牙の店床的利 用価值について.日本齿科評詥 367: 1041973.

23) Meryman, H.T.: The relationship between dehydration and freezing injury in the human erythrocyte. in Cellular injury and resistance in freezing organisms. Asahina, E. ed. The Institution of low temperature science Hokkaido Univ, Sapporo, 1967, p231.

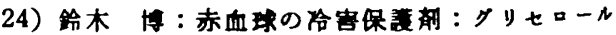

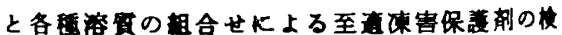
討. 低温医学 1: 31975.

25) Niwayama, G., Johnson, C.F., Grace, J.T., et al.: The kinetics of dimethylsulfoxide (DMSO) and glycerol in cultured cells during preincubation and washing for cell storage. Cryobiology 3: 3851967.

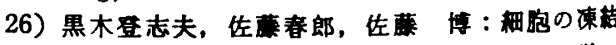
保存法一生命の半永久的保存は可能か。医学の 
Vol. 27 No. 6

あゆみ 69: 4061969.

27）市川洋一：移植のための骨噵細胞湅結保存，低 温医学 1：125 1975.

28) Alink, G.M., Verheul, C.C., Agterberg, J., et al.: Viability and morphology of rat heart cell after freezing and thawing of the whole heart. Cryobiology 15: 441978.

29）福西孝信，他：鲟期りンパ球凍秥保存の研究. 低温医学 1：119 1975.

30) 兽和 正, 他：顆粒球の低温保存、低温医学 2: 3151976.

31) Rowe, A.W.: The significance of the aque- ous-ice phase transformation during controlled rate cooling of biological specimens. in Cult. ure injury and resistance in freezing organisms. Asahina, E. ed. The institute of low temperature science Hokkaido Univ, Sapporo, 1967, p21.

32) Pawtel, B., Lukomska, B., Szmurlo, W.F., et al.: Programmed freezing of macrophages. Acta Med Pol 19: 1831978.

33）酒井昭：堷細胞の波体空省中での湅綃保 存。組織培数 4：219 1978. 